\title{
The Role of Tree Shades for Adaptive Thermal Comfort
}

\author{
Rabiatul Adawiyah Nasir ${ }^{1}$, Sabarinah Sh Ahmad ${ }^{1,2}$, \\ Azni Zain-Ahmed ${ }^{3}$, Norhati Ibrahim ${ }^{1,2}$ \\ ${ }^{1}$ Faculty of Architecture, Planning and Surveying, Universiti Teknologi MARA, 40450 Shah Alam, Malaysia \\ ${ }^{2}$ Community of Research, Green Technology and Sustainable Development, \\ ${ }^{3}$ Institute of Science, \\ Universiti Teknologi MARA, 40450 Shah Alam, Malaysia \\ rabiatul9425@salam.uitm.edu.my
}

\begin{abstract}
Trees are an essential part of every community in an urban area. The trees' canopies and crowns provide comfortable conditions for outdoor activities and recreation. This paper presents the simulations of tree shades, which is proven to enhance the microclimate of an urban park. The results showed that the tree shades sustained the microclimate of the park; lower the air temperature control the thermal comfort and maintained the wind flow. The implications of the outcomes show significant modifications in the human comfort sensation concerning the restoration of urban setting with tree shades.
\end{abstract}

Keywords: Trees; Canopies; Thermal Comfort; Urban Park

eISSN 2398-4295 @ 2018. The Authors. Published for AMER ABRA cE-Bs by e-International Publishing House, Ltd., UK. This is an open-access article under the CC BY-NC-ND license (http://creativecommons.org/licenses/bync-nd/4.0/). Peer-review under responsibility of AMER (Association of Malaysian Environment-Behaviour Researchers), ABRA (Association of Behavioural Researchers on Asians) and CE-Bs (Centre for EnvironmentBehaviour Studies), Faculty of Architecture, Planning \& Surveying, Universiti Teknologi MARA, Malaysia.

http://dx.doi.org/10.21834/ajbes.v3i11.113 


\subsection{Introduction}

Trees are an essential part of every community in an urban area. In an urban setting, trees are planted along streets, riverbanks, in recreation areas and parks and sometimes conserved in urban forests and arboretums. In the hot and humid region, trees in urban parks provide urbanites with shaded areas during the late mornings and afternoons. The trees canopies and crown provide comfortable conditions for outdoor activities and recreation. In addition, using trees in cities to refract the sunlight and cast shades reduces the urban heat island effect caused by open spaces, hardscapes and complex surfaces of urban structures. The expansion of the urban areas draws the awareness of the adaptation of the urban climate condition. This study aims to show the importance of the trees' canopies and crowns and the role of tree shades towards urban regeneration by analysing the trees' shading patterns through computer simulations. This paper presents the simulations of the algorithm for the trees shades, which is proven to enhance the microclimate of the area. The simulation series showed the comparison of four different scenarios to verify the changes related to canopies and crowns on plants structure and composition. The study employed iteration algorithm to experiment different conditions of scenarios. The results showed that the tree shades sustained the microclimate of the area; lower the air temperature control the thermal comfort and maintained the wind flow. The implications of the outcomes show significant modifications in the human comfort sensation concerning the restoration of urban setting with tree shades, which, would be a positive aspect towards urban regeneration.

\subsection{Literature Review}

\section{The implication of green area in urban form}

The causes of Urban Heat Island (UHI) are heat stress and other effects triggered by the densely built environment when the natural landscapes are with buildings and roads. The microclimate condition has significant impacts on urban occupants, as the higher temperature in cities will result in increased energy use for indoor and cooling and higher water demand for landscape mitigation. The high humidity in tropical cities combined with high air temperature will create discomfort and undermine the function of outdoor places. As a result, the demand for a better microclimate condition is more pronounced today than decades ago. Shading from trees has proven to improve the condition of human energy heat balance while doing outdoor activities and improve the indoor conditions of building by reducing the solar radiation on the building facades. Previous studies (Akbari, Pomerantz, \& Taha, 2001; Mohd Fairuz Shahidan, Jones, Gwilliam, \& Salleh, 2012) have verified that the density of the tree crown would reduce the air temperature under the tree between 2 and $4{ }^{\circ} \mathrm{C}$. When the UHI effect is correlated with the trees density, the result showed that a significant value of green area or vice versa (Chow \& Brazel, 2012; Gago, Roldan, Pacheco-Torres, \& Ordóñez, 2013). Besides energy consideration, high temperatures could increase health risks and atmospheric pollution, as it is known that the greenhouse effect contributes towards global warming, higher energy demand and emission. Hence, the urban green areas and 
infrastructure should be maintained in tropical hot and humid cities to guarantee the wellbeing of the urban communities (Mansor, Said, \& Mohamad, 2010).

Therefore, the strategies of planting more vegetation in urban areas are used to alleviate the greenhouse effect since vegetation plays a significant role in regulating the urban climate. In a hot climate, vegetation planted around buildings can alter the energy balance as well as cooling energy requirements of buildings by sheltering windows, walls, and rooftop from strong solar radiation as well as radiation reflected from the surroundings. Trees could help reduce the $\mathrm{CO} 2$ level, increase $\mathrm{O} 2$ and the quality of life (Borhan, Ahmed, \& Hitam, 2013).

\section{Outdoor thermal comfort for urban regeneration in hot and humid climate}

Previous studies discovered the role of green area in mitigating the UHI effect in tropical cities (Emmanuel, 2005; Wong \& Yu, 2005). In those studies, the air temperature across the city was reduced between 1 and $4^{\circ} \mathrm{C}$ by the green area. The results showed that urban green areas can improve the urban microclimate and mitigate the UHI effect by reducing the ambient temperature. In addition, earlier investigations on the adaptation of thermal comfort in Shah Alam showed that the shaded area played an important role to sustain the sensation of comfort among the public (Nasir, Ahmad, \& Ahmed, 2012, 2013). The results confirmed the practice of adaptive thermal comfort when the respondents perceived the microclimatic condition to be satisfactory. They perceived better microclimatic conditions than what was measured. This may show how the respondents think about their microclimatic condition and adapt to it effortlessly. The perception and the sensation of thermal comfort are vital in urban form (Kariminia \& Ahmad, 2013). Thus, further study on what settings should be provided in various types of urban from is important to sustain the urban regeneration. This study emphasises the condition of certain criteria of urban park setting could offer better microclimatic conditions than an urban park without any planning strategy.

\subsection{Methodology}

\section{Field study}

The site of this study was at the Shah Alam Lake Garden, Selangor, Malaysia $\left(3^{\circ} 5^{\prime} 00^{\prime \prime} \mathrm{N}\right.$, $\left.101^{\circ} 32^{\prime} 00^{\prime} \mathrm{E}\right)$. The chosen location for matured trees and the soil surround the field study covered with grass. The study area is approximately 2 acres. The exact study area is called Tasik Barat, Taman Tasik Shah Alam (Figure 1). The main instrument used in the measurement is the weather station (RainWise). The equipment measured air temperature $\left(T_{a}\right)$, relative humidity $(R H)$, wind velocity $(v)$, wind direction, rainfall and solar radiation $\left(I_{r}\right)$. The microclimatic conditions were measured simultaneously using portable weather data instruments at 10-minute intervals. The sensors were installed at the centre of perimeter of the study area in Figure 1. 


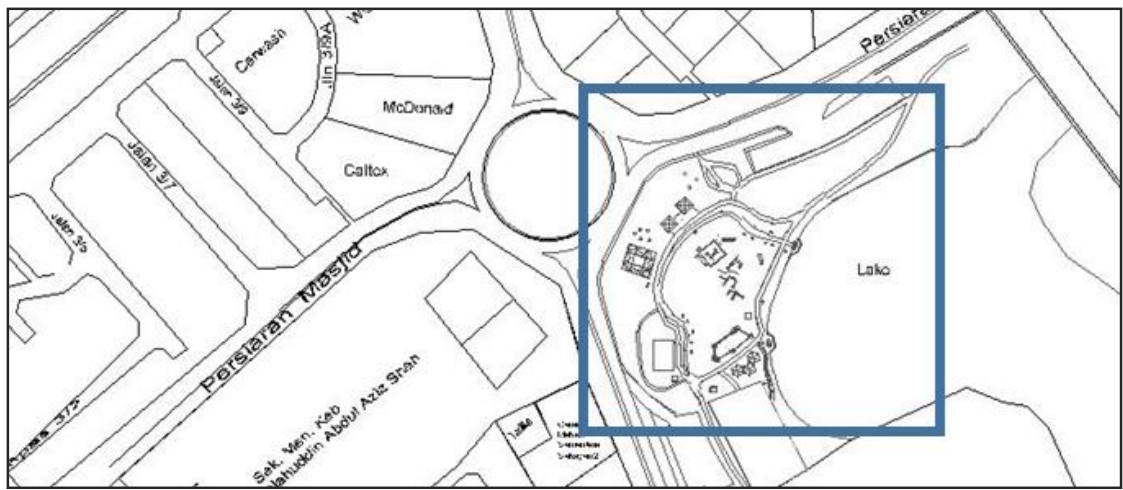

Figure 1: The study area, Tasik Barat, Taman Tasik Shah Alam

\section{Vegetation cover profiling}

The vegetation on the site was recorded using Global Position System (GPS) and grid plotted in the CAD system. The trees' configurations such as the Leaf Area Index (LAI) has been set according to a previous study (Mohd Fairuz Shahidan et al., 2012). The layout of the area was then outlined in the Envi-Met simulation programme. The main vegetation cover is Samanea saman, Peltophorum pterocarpum, Tabebuia pentaphylla and Pterocarpus indicus.

The estimation of the vegetation profile is based on the combining an allometric method for tree leaf area with the MacArthur-Horn (MH) method (MacArthur \& Horn, 1969; Sumida et al., 2009). This method using a portable laser rangefinder for the measurements and calculate the fragmented of LAD of each 10 sections. The details were then, included in the simulations to be modeled. The tree species; Peltophorum pterocarpum, Tabebuia pentaphylla, Pterocarpus indicus and Samanea saman is the major species being planted in the study area. The height and the vegetation profile has been determined by the average size of the whole vegetation. The arrangements of the 'extra trees' scenarios were randomly tabulated. This study evaluated the differences in cooling effect of only four species of trees and one species of ground cover. The theory has proven that vegetation density of trees and tree characteristics affect the efficiency of cooling effect.

\section{Envi-met simulation}

"ENVI-met is a three-dimensional non-hydrostatic model for the simulation of Surface-PlantAir interactions in the urban environments" (Bruse \& Team, n.d.). It is designed for microscale with a typical horizontal resolution of $0.5-10 \mathrm{~m}$, and a typical time frame of 24-48 $\mathrm{h}$ with a time step of $10 \mathrm{~s}$. This placement of vegetation was simulated as is Figure 2(a) and an additional $80 \%$ in 'extra trees' Figure 2(b) scenarios to observe the differences in the results.

This study decides 10 March 2012 as the selected day for the simulations. Envi-met programme is used to compare the thermal conditions with the three different scenarios (Figure 2); Scenario 1- existing settings: This scenario is the base case, which simulates the current thermal conditions of Taman Tasik Shah Alam (Tasik Barat) and its surroundings. 
Scenario 2- extra trees: In this scenario, a broad change on vegetation cover is done surrounding of Taman Tasik Shah Alam. High-density trees and its surroundings are examined. Scenario 3-ground cover: In this scenario, all plants in the park are removed but the soil and ground cover (grass) are retained. The thermal conditions of the areas were investigated.

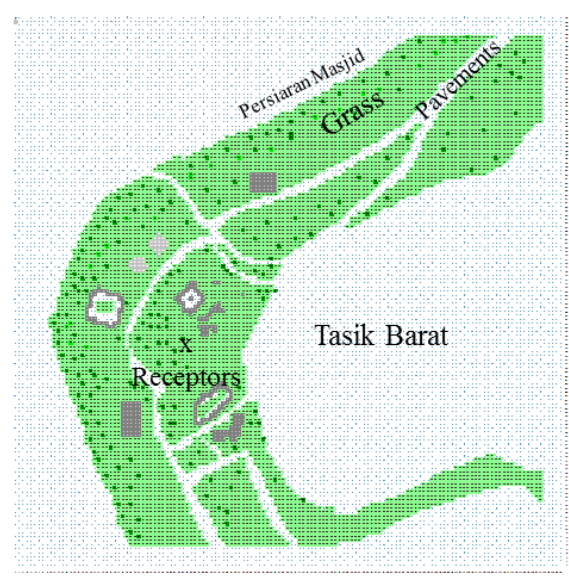

(a)

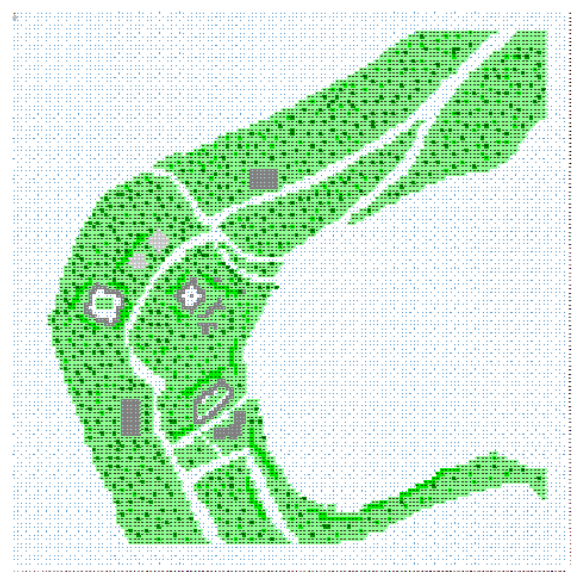

(b)

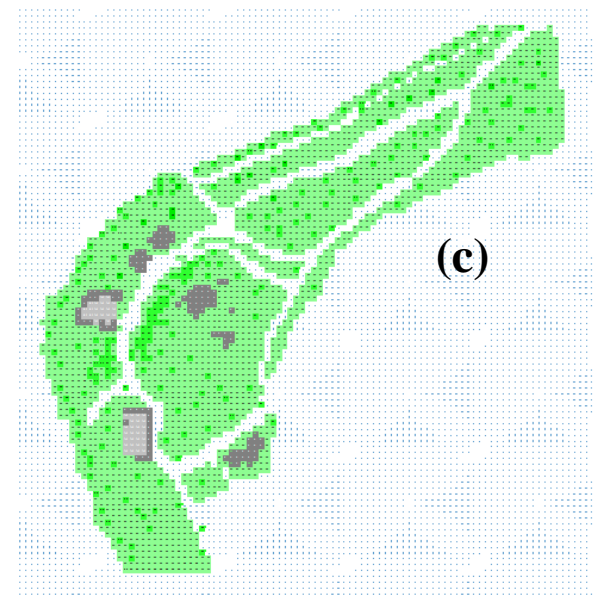

Figure 2: Three scenarios: (a) existing settings; (b) extra vegetation; (c) ground cover 
Thirteen hours of simulation time are employed since it could give the model 12 hours (0700-1900) to acquire the optimum data for the daytime. The data was modeled every hour. The configurations of the main data of the Envi-Met simulations are as shown in Table 2.

\subsection{Results and Discussions}

The simulated microclimate parameters were Air Temperature (Ta), Relative Humidity (RH), Wind Velocity (v) and Mean Radiant Temperature (Tmrt) as shown in Table 3. These data indicate the comparisons between three scenarios in an hour simulation interval. The highest temperature present between 1500 and $1600 \mathrm{hrs}$. The relative humidity is at the highest state before $1000 \mathrm{hrs}$. However, wind speed evaluation cannot be determined by hours, yet, the scenario differ the evaluation.

Table 3. Simulated microclimate parameters

\begin{tabular}{|c|c|c|c|c|c|c|c|c|c|c|c|c|}
\hline \multicolumn{4}{|c|}{ Air Temperature $\left({ }^{\circ} \mathrm{C}\right)$} & \multicolumn{3}{|c|}{ Relative Humidity (\%) } & \multicolumn{3}{|c|}{ Wind Speed $(\mathrm{m} / \mathrm{s})$} & \multicolumn{2}{|c|}{$\mathrm{T}_{\mathrm{mrt}}\left({ }^{\circ} \mathrm{C}\right)$} & \multirow[b]{2}{*}{$\begin{array}{l}\text { Ground } \\
\text { Cover } \\
\end{array}$} \\
\hline$\underline{\text { Time }}$ & $\begin{array}{l}\text { Exist- } \\
\text { ing }\end{array}$ & $\begin{array}{l}\text { Extra } \\
\text { Tress } \\
\end{array}$ & $\begin{array}{l}\text { Ground } \\
\text { Cover } \\
\end{array}$ & $\begin{array}{l}\text { Exist- } \\
\text { ing }\end{array}$ & $\begin{array}{l}\text { Extra } \\
\text { Tress } \\
\end{array}$ & $\begin{array}{l}\text { Ground } \\
\text { Cover }\end{array}$ & $\begin{array}{l}\text { Exist } \\
\text {-ing }\end{array}$ & $\begin{array}{l}\text { Extra } \\
\text { Tress } \\
\end{array}$ & $\begin{array}{l}\text { Ground } \\
\text { Cover }\end{array}$ & $\begin{array}{l}\text { Exist } \\
\text {-ing }\end{array}$ & $\begin{array}{l}\text { Extra } \\
\text { Tress }\end{array}$ & \\
\hline 7:00 & 23.9 & 24.0 & 23.9 & 87.1 & 86.9 & 87.3 & 2.0 & $\begin{array}{l}1.9 \\
1 .\end{array}$ & 1.9 & 16.0 & 16.0 & 16.1 \\
\hline 8:00 & 24.2 & 24.2 & 24.1 & 86.3 & 86.2 & 86.7 & 1.9 & $\begin{array}{l}9 \\
1 .\end{array}$ & 1.8 & 16.3 & 16.3 & 16.4 \\
\hline 9:00 & 25.0 & 24.9 & 24.9 & 84.7 & 84.8 & 85.1 & 1.8 & $\begin{array}{l}9 \\
1 .\end{array}$ & 1.6 & 49.2 & 37.8 & 51.1 \\
\hline 10:00 & 26.1 & 25.9 & 26.1 & 82.7 & 83.0 & 82.9 & 1.8 & $\begin{array}{l}9 \\
2 .\end{array}$ & 1.4 & 45.0 & 29.2 & 58.5 \\
\hline 11:00 & 27.5 & 27.3 & 27.6 & 80.4 & 80.7 & 80.4 & 1.9 & $\begin{array}{l}0 \\
2 .\end{array}$ & 1.4 & 44.6 & 42.3 & 58.2 \\
\hline $12: 00$ & 28.6 & 28.4 & 28.6 & 78.7 & 79.0 & 78.9 & 1.9 & $\begin{array}{l}0 \\
2 .\end{array}$ & 1.4 & 53.9 & 53.3 & 53.7 \\
\hline 13:00 & 29.3 & 29.1 & 29.4 & 77.4 & 77.7 & 77.5 & 2.0 & $\begin{array}{l}1 \\
2 .\end{array}$ & 1.4 & 47.4 & 47.2 & 47.1 \\
\hline $14: 00$ & 29.9 & 29.7 & 29.9 & 76.3 & 76.6 & 76.4 & 2.0 & $\begin{array}{l}1 \\
2 .\end{array}$ & 1.4 & 49.1 & 48.9 & 48.8 \\
\hline $15: 00$ & 30.1 & 29.9 & 30.2 & 75.7 & 76.1 & 75.7 & 2.0 & $\begin{array}{l}1 \\
2 .\end{array}$ & 1.4 & 56.3 & 51.4 & 56.0 \\
\hline $16: 00$ & 30.1 & 29.9 & 30.2 & 75.5 & 76.0 & 75.3 & 2.0 & $\begin{array}{l}1 \\
2 .\end{array}$ & 1.4 & 52.0 & 48.2 & 60.3 \\
\hline $17: 00$ & 29.8 & 29.6 & 29.9 & 75.9 & 76.4 & 75.7 & 2.0 & $\begin{array}{l}1 \\
2 .\end{array}$ & 1.4 & 46.7 & 46.5 & 59.6 \\
\hline 18:00 & 29.3 & 29.1 & 29.3 & 77.0 & 77.3 & 76.8 & 2.0 & $\begin{array}{l}1 \\
2 .\end{array}$ & 1.3 & 38.2 & 32.9 & 49.0 \\
\hline 19:00 & 28.5 & 28.4 & 28.4 & 78.4 & 78.6 & 78.6 & 2.0 & 1 & 1.3 & 21.0 & 20.9 & 21.0 \\
\hline
\end{tabular}

Figure 3 displays a scatterplot of the association of air temperature between the real condition (measurements using weather station) and simulated data in Envi-Met. The comparison of hourly data logged for 10 March 2012 of air temperature in measurements and simulations as shown in the scatterplot clearly indicates that there is a positive relationship between the measurements and simulations. 


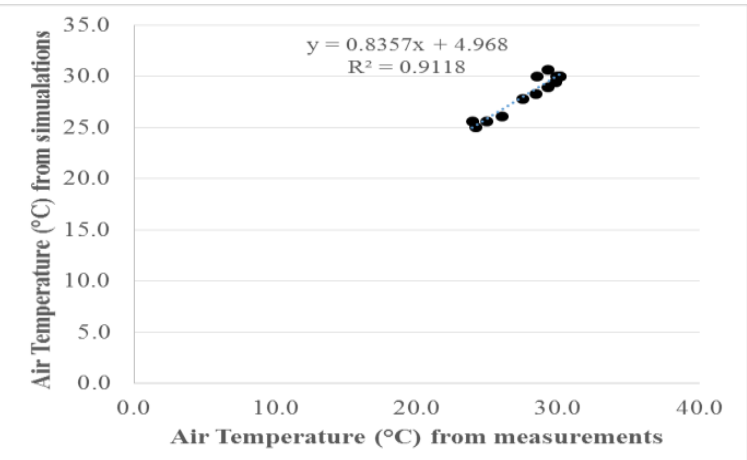

Figure 3: The correlation analysis between measurements and simulated data

Figure 4, Figure 5 and Figure 6 show the comparisons of air temperature (Kelvin), Relative Humidity (\%) and wind velocity $(\mathrm{m} / \mathrm{s})$ between three scenarios; 'existing setting', 'extra trees' and 'ground cover'. The 'extra trees' shows the reduced ambient temperature during daytime. The average of one-degree Celcius reductions in twelve hours proved that the denseness of mature trees would reduce the ambient temperature perfectly (Figure 4). Moreover, the relative humidity (\%) is higher in the 'extra trees' scenarios. The lowest temperature and higher relative humidity of the scenarios offer a better microclimate condition. Moreover, the ventilation of the 'extra trees' scenarios is the best due to the channel effect by the plants.

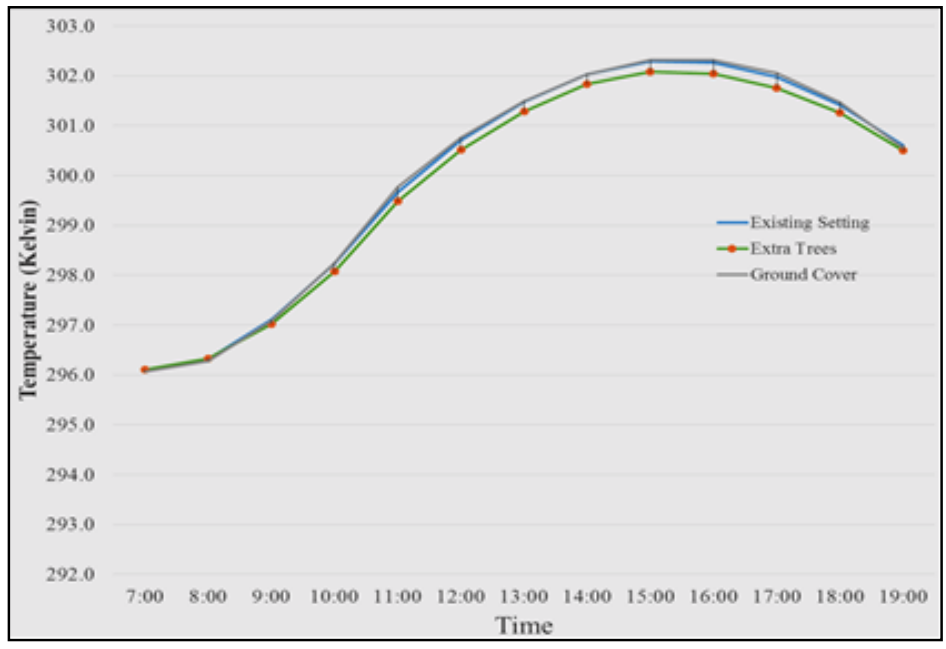

Figure 4: The comparisons of air temperature (Kelvin) between three scenarios 


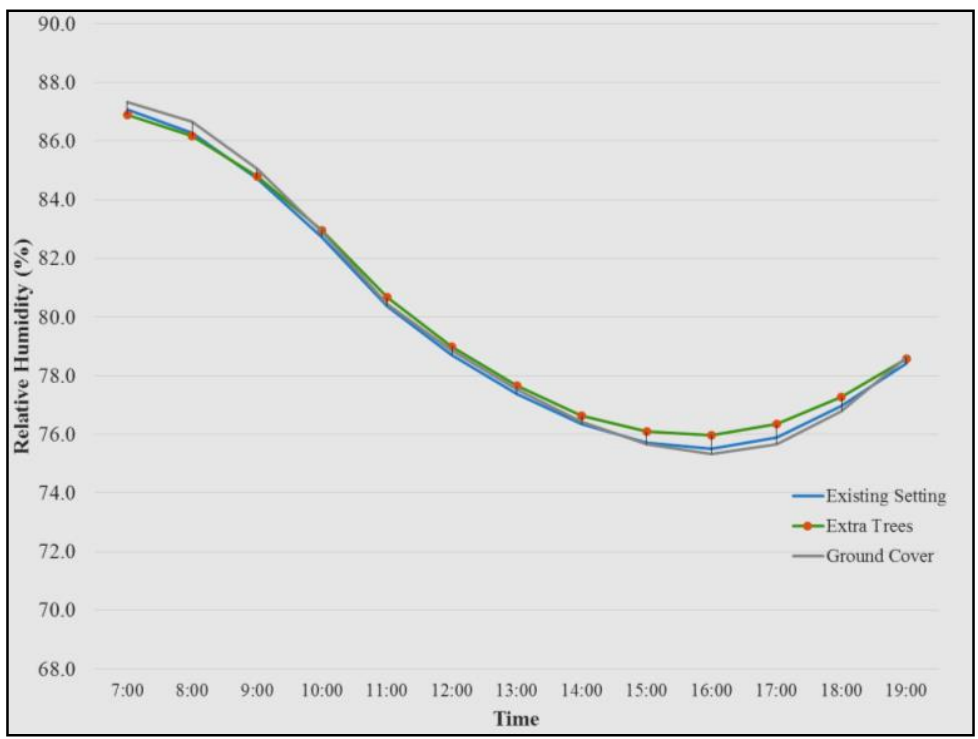

Figure 5: The comparisons of relative humidity (\%)between three scenarios

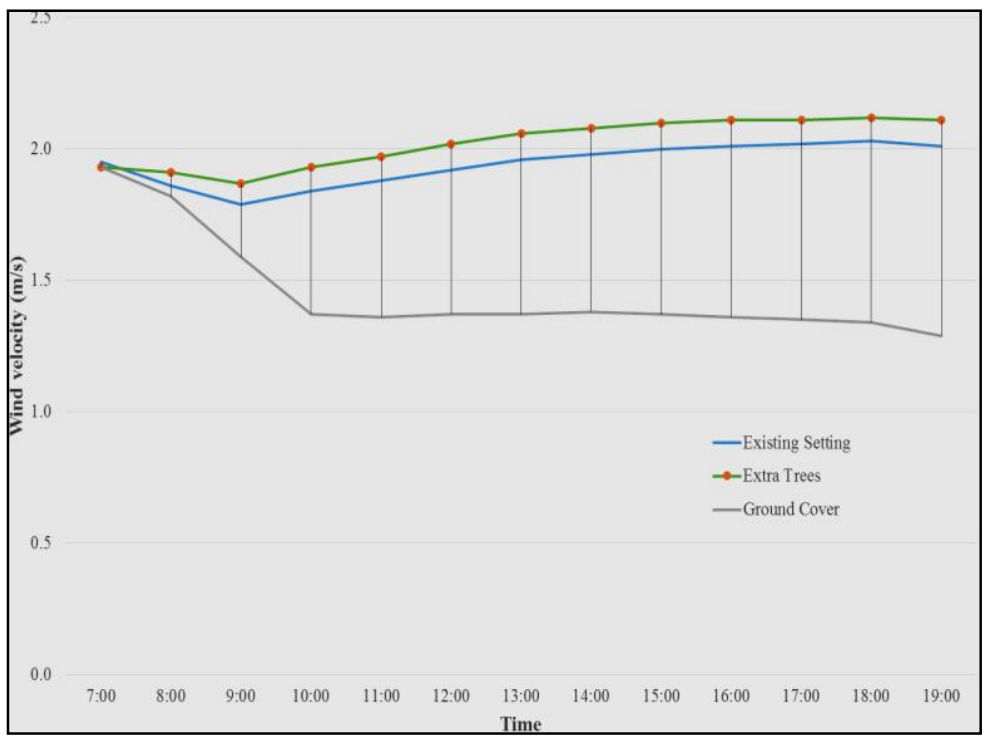

Figure 6: The comparisons of wind velocity $(\mathrm{m} / \mathrm{s})$ between three scenarios 
The chart also explains shows that there is a correlation between 'extra trees' and 'ground cover'. When the 'extra trees' scenario shows lowest degree of temperature and highest degree on humidity and winds speed, there is vice versa on the 'ground cover' scenario. This trend supports the theory that the denser vegetation and mature plants are established in the area, the microclimate condition improve into the comfort state of thermal comfort condition

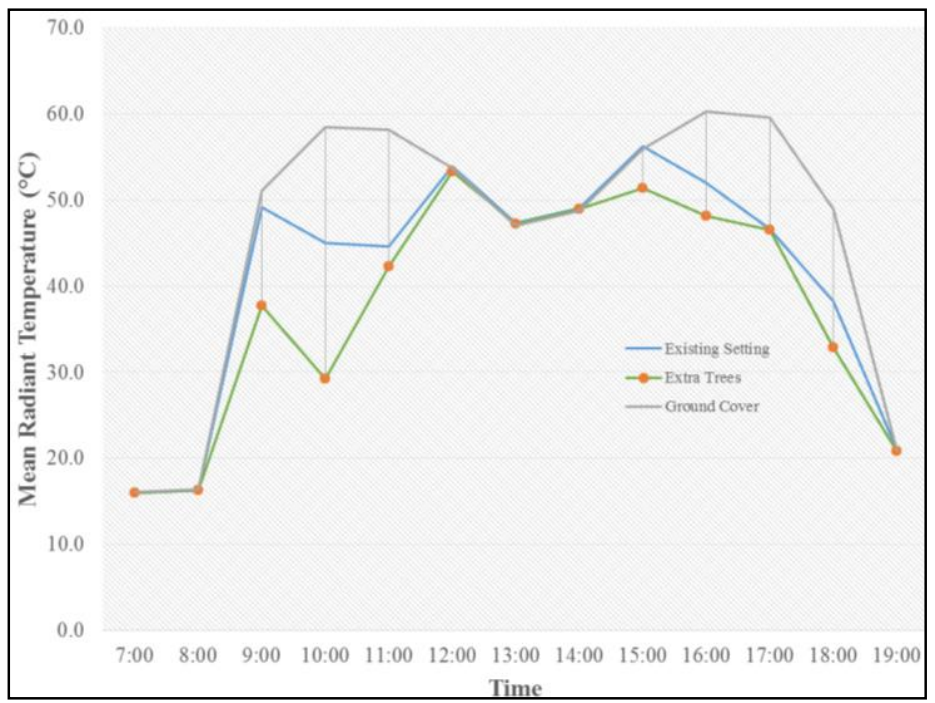

Figure 7: The comparisons of Mean Radiant Temperature ( $\left.T_{\mathrm{mrt}}\right)$ between three scenarios

Furthermore, it is important to analyse human energy balance from the simulations in order to study the thermal comfort parameters that the human body is exposed to. The Mean Radiant Temperature ( $\left.T_{\mathrm{mrt}}\right)$ is defined as the 'uniform temperature of an imaginary enclosure in which the radiant heat transfer from the human body equals the radiant heat transfer in the actual non-uniform enclosure' (ANSI/ASHRAE Standard 55, 2004). The simulations data shows that the cooling effect is significantly governed by the extra trees scenarios (Figure 7). Figure 7 also shows that between noon and 1400h, all three scenarios recorded the same results due to the shadow pattern effect (Lindberg, Holmer, \& Thorsson, 2008).

\subsection{Conclusion}

This study confirmed that the urban form achieved satisfactory thermal comfort levels based on different physical configurations of the urban park settings. It was found that to gain optimum energy heat balance of the human body, urban form should provide the area with lower air temperature, higher humidity and good ventilation. The structure of the surface also played an important role in making the setting as a place with better microclimate. The shaded area planted with mature plants, set with full canopy and tree crown undoubtedly 
would give the public an opportunity to optimize the outdoor park in the daytime. This study proves that the plants in the urban environment have functions for controlling the microclimate, decreasing air temperature, increasing humidity and modulate the wind ventilation. Tree species and the growth of the tree will give significant and important findings for the designers. The trees selection become important as the tree canopies provide different type of shading. Although the profits of green area is intangible, yet, the vegetation is considerably value for provide the community the place for social communal. The amount of dollar and cents can be calculated if the carbon of pollution can be reduced and calculated, so it can be tangible. Thus, the importance of the green area is sustainable.

Furthermore, the outcome of this study offers a solution to the issue of heat stress. Also, it suggests the proposed way to mitigate the Urban Heat Island (UHI). The denser and mature trees for optimization of green area, and at the same time give the community a place for urban regeneration. The importance of trees should be emphasizes by the designer, community and the authorities for the sustainable community for the generations.

\section{Acknowledgement}

This research has been funded by the Ministry of Higher Education under the Exploratory Research Grant Scheme (ERGS) file no: 600-RMI/ERGS 5/3 (45/2013), the Fundamental Research Grant Scheme (FRGS) file no: 600-RMI/ST/FRGS 5/3/Fst (104/2012) and RMI/UiTM Excellence Fund. Universiti Teknologi MARA and Majlis Bandaraya Shah Alam also support this research.

\section{References}

Akbari, H., Pomerantz, M., \& Taha, H. (2001). Cool surfaces and shade trees to reduce energy use and improve air quality in urban areas. Solar Energy, 70(3), 295-310.

ANSI/ASHRAE Standard 55, Thermal Environmental Conditions for Human Occupancy (2004). Atlanta: American society of heating, refrigerating, and air-conditioning engineers.

Bruse, M., \& Team. (n.d.). Welcome to ENVI-met $®$ ! Retrieved June 12, 2012, fromhttp://www.envi-met.com/

Chow, W. T. L., \& Brazel, A. J. (2012). Assessing xeriscaping as a sustainable heat island mitigation approach for a desert city. Building and Environment, 47(1), 170-181.

Emmanuel, R. (2005). Thermal comfort implications of urbanization in a warm-humid city: the Colombo Metropolitan Region (CMR), Sri Lanka. Building and Environment, 40(12), 1591-1601.

Gago, E. J., Roldan, J., Pacheco-Torres, R., \& Ordóñez, J. (2013). The city and urban heat islands: A review of strategies to mitigate adverse effects. Renewable and Sustainable Energy Reviews, 25(0), 749-758.

Kariminia, S., \& Ahmad, S. S. (2013). Dependence of Visitors' Thermal Sensations on Built Environments at an Urban Square. Procedia - Social and Behavioral Sciences, 85, 523-534. 
Lindberg, F., Holmer, B., \& Thorsson, S. (2008). SOLWEIG 1.0 - Modelling spatial variations of 3D radiant fluxes and mean radiant temperature in complex urban settings. International Journal of Biometeorology, 52(7), 697-713.

MacArthur, R. H., \& Horn, J. W. (1969). Foliage profiles by vertical measurements. Ecology, 50(5), 802-804.

Nasir, R. A., Ahmad, S. S., \& Ahmed, A. Z. (2012). Psychological Adaptation of Outdoor Thermal Comfort in Shaded Green Spaces in Malaysia. Procedia - Social and Behavioral Sciences, 68(0), 865-878.

Nasir, R. A., Ahmad, S. S., \& Ahmed, A. Z. (2013). Physical Activity and Human Comfort Correlation in an Urban Park in Hot and Humid Conditions. Procedia-Social and Behavioral Sciences, 105, 598-609.

Shahidan, M. F., Jones, P. J., Gwilliam, J., \& Salleh, E. (2012). An evaluation of outdoor and building environment cooling achieved through combination modification of trees with ground materials. Building and Environment, 58(0), 245-257.

Shahidan, M. F., Shariff, M. K. M., Jones, P., Salleh, E., \& Abdullah, A. M. (2010). A comparison of Mesua ferrea L. and Hura crepitans $L$. for shade creation and radiation modification in improving thermal comfort. Landscape and Urban Planning, 97(3), 168-181.

Sumida, A., Nakai, T., Yamada, M., Ono, K., Uemura, S., \& Hara, T. (2009). Ground-based estimation of leaf area index and vertical distribution of leaf area density in a Betula Ermanii Forest. Silva Fennica, 43(5), 799-816.

Wong, N. H., \& Yu, C. (2005). Study of green areas and urban heat island in a tropical city. Habitat International, 29(3), 547-558. 